\title{
COASTAL VULNERABILITY INDEX DEVELOPMENT: A REVIEW
}

\author{
A. I. A. Hamid ${ }^{1 *}$, A. H. M. Din ${ }^{1,2 *}$, N. Yusof ${ }^{3}$, N.M. Abdullah ${ }^{4}$, A. H. $\operatorname{Omar}^{1}$ and M. F. A. Khanan ${ }^{3}$ \\ ${ }^{1}$ Geomatic Innovation Research Group (GnG), ${ }^{2}$ Geoscience and Digital Earth Centre (INSTEG), Faculty of Built Environment and \\ Surveying, Universiti Teknologi Malaysia, 81310 Johor Bahru, Johor, Malaysia. \\ ${ }^{3}$ Department of Geoinformation, Faculty of Built Environment and Surveying, Universiti Teknologi Malaysia, 81310 Johor Bahru, \\ Johor, Malaysia \\ ${ }^{4}$ Faculty of Civil and Environmental Engineering, Universiti Tun Hussein Onn Malaysia, 86400 Parit Raja, Johor, Malaysia \\ *amihassan@utm.my
}

KEY WORDS: Coastal Vulnerability Index (CVI), Physical Variables, Index Development

\begin{abstract}
:
Coastal vulnerability Index (CVI), is one of the predictive approaches to coastal classification by incorporating various coastal variables. This approach is favoured in the coastal investigation as it simplifies a number of complex parameters. However, it comes greatly as to why such assessment is developed in the first place; a) to facilitate coastal management in recent coastal condition, b) to classify potential shoreline responses to future sea-level rise, and c) for management of data storage. Index development in coastal investigation is one of the present-day technique used to estimate the vulnerability of the coast and is affected by a diverse range of variables. The widespread use of contemporary technology nowadays has led to a favourable coastal component to be considered in determining coastal vulnerability and environmental risk analysis. Therefore, it must be guided by acknowledging appropriate data to be used at spatial scale of interest, the geomorphology of the area concerns and etc. USA and European countries like Northern Ireland are one of the forefront country in addressing the significance of CVI in protecting coastal area. A stepwise approach to development of CVI is discussed in detail in this paper. Besides, the potential of including coastal components based on special characteristic at particular coasts for coastal vulnerability analysis are also reviewed. CVI eventually will assist coastal communities in providing guidance for mitigation of coastal threats in future urban development.
\end{abstract}

\section{INTRODUCTION}

Sustaining coastal processes, which characterized by important ecological and natural value, are essential since they provide ecosystem service that is deemed important for human wellbeing (MEA, 2005; Ramieri et al., 2011). A wide number of often conflicting-human activities in the coastal zone already intensify the interaction of coastal ecosystem. Climate change and sea level rise furthermore is placing increasing tension on coastal region which are severely affected by the major human activity over time. A relatively small increase in sea level could affect natural coastal systems (Din et al., 2019). In particular, in 2100 the rise can be up to $1 \mathrm{~m}$, affecting the coastal property zone where mostly people are living here in the near year 2040 (Hamid et al., 2018).

Coastal vulnerability is established on the human conception and judgement concerning risk to various elements of the natural system from variety of sources (McFadden, 2007; McLaughlin and Cooper, 2010). Coastal vulnerability is precipitated from the variability of physical, ecological and human characteristics thus prompted an effort to classify coasts using multidisciplinary information (LOICZ, 1995; Cooper and McLauglin, 1998). To be understood by the non-specialist, earth scientist has developed numerous approaches for ease of understanding of complex, multivariate environmental data. This paper reviews published coastal vulnerability indices developed to assess and categorize response to progressive change in the dynamic of coastal zone around the world.

\section{COASTAL VULNERABILITY INDEX (CVI)}

\subsection{Coastal Classification}

Coastal classification from indices approach generally is based upon on the relative contributions of three groups: 1) Socioeconomic, 2) Coastal characteristics and 3) Coastal forcing variables (see Figure 1).

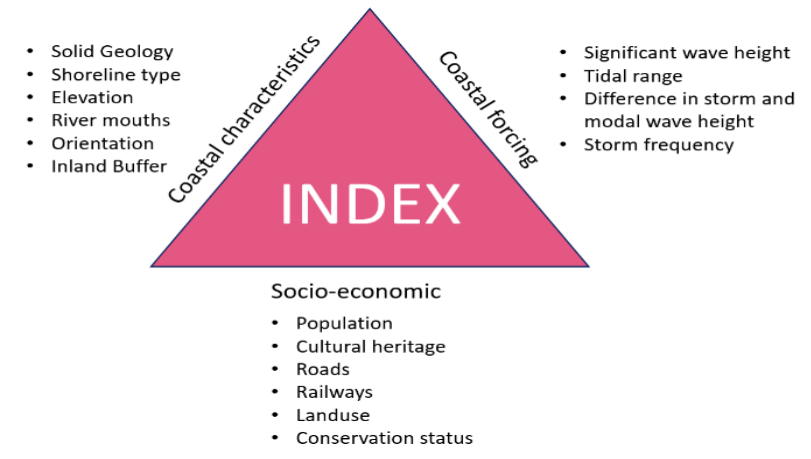

Figure 1. Variable classification for indices (modified from McLaughlin and Cooper, 2010)

According to McLaughlin and Cooper (2010), the three elements of physical coastal characteristics, wave forcing and socio-economic characteristics contribute to overall vulnerability. These multidisciplinary variables, represented by diverse type of data literally complex in assembling for coastal

\footnotetext{
* Corresponding author
} 
vulnerability assessment. This index-based method simplifies a number of complex and interacting parameters is widely used to measure vulnerability of the coast globally.

\subsection{Choosing Coastal Variables}

Choosing coastal variables are actually very tricky. Previous study shows that numbers of variables in published CVI can vary dramatically. Back in time, past researchers believed that the more variables affecting the coast that taken consideration, the more correct will be the resulting zone (Dal Cin and Simeoni, 1989). Williams et al. (1993) used around 54 variables to investigate the coastal dune vulnerability in Devon and Cornwall, however Quelennec (1989) used only three (3) principal variables to identify high-risk coastal areas in Europe. The notion to use as many variables as possible for coastal vulnerability assessment is not necessarily true since using many variables indicate risky correlation among the data (McLaughlin and Cooper, 2010). Since then, in order to develop assessment at national scale, Thieler and HammarKlose (1999) employed six (6) physical variables that contributed to sea-level rise-related coastal changes; 1) geomorphology, 2) shoreline erosion and accretion rates ( $\mathrm{m} / \mathrm{yr}$ ), 3) coastal slope (percent), 4) rate of relative sea-level rise $(\mathrm{mm} / \mathrm{yr}), 5)$ mean tidal range $(\mathrm{m})$, and 6) mean wave height $(\mathrm{m})$, are used by scientists around the world as primary elements in investigating CVI. Each variable was assigned a relative risk value based on the potential magnitude of its contribution to physical changes on the coast as sea-level rises.

Nonetheless, as reported by Gornitz et al. (1993), socioeconomic variables reckon to inherent cultural bias to the index since socio-economic variables are difficult to quantify. The inclusion of economic factors is the common recommendation made by scientists for improvement of indices (Cooper and McLaughlin, 1998) though McFadden (2007) suggests that integrating physical and socio-economic is ideals, to become a trans-disciplinary concept.

\subsection{Index Ranking and Calculation}

Each variable is assign to a rank to indicate its contribution to vulnerability. Hammar-Klose and Thieler (2001) ranked six (6) physical variables on a linear scale from 1-5 in order of increasing vulnerability due to sea-level rise. In other words, a value of 1 represents the lowest risk and 5 represents the highest risk. The database includes both quantitative and qualitative information. Thus, numerical variables are assigned a risk ranking based on data value ranges, while the non-numerical geomorphology variable is ranked according to the relative resistance of a given landform to erosion as shown in Table 1.

Table 1. Ranking of coastal vulnerability index variables for the U.S. Gulf of Mexico (Hammar-Klose and Thieler, 2001)

\begin{tabular}{|c|c|c|c|c|c|}
\hline & \multicolumn{5}{|c|}{ Ranking of coastal vulnerability index } \\
\hline & Very low & Low & Moderate & High & Very High \\
\hline VARIABLE & 1 & 2 & 3 & 4 & 5 \\
\hline Geomorphology & $\begin{array}{l}\text { Rocky, cliffed } \\
\text { coasts, Fiords } \\
\text { Fiards }\end{array}$ & $\begin{array}{l}\text { Medium cliffs, } \\
\text { Indented coasts }\end{array}$ & $\begin{array}{l}\text { Low cliffs, } \\
\text { Glacial drift, } \\
\text { Alluvial plains }\end{array}$ & $\begin{array}{l}\text { Cobble } \\
\text { beaches, } \\
\text { Estuary, } \\
\text { Lagoon }\end{array}$ & $\begin{array}{l}\text { Barrier beaches, } \\
\text { Sand Beaches, Salt } \\
\text { marsh, Mud flats, } \\
\text { Deltas, Mangrove, } \\
\text { Coral reefs }\end{array}$ \\
\hline Coastal slope (\%) & $>0.115$ & $0.115-0.055$ & $0.055-0.035$ & $0.035-0.022$ & $<0.022$ \\
\hline $\begin{array}{l}\text { Relative sea-level } \\
\text { change (mm/yr) }\end{array}$ & $<1.8$ & $1.8-2.5$ & $2.5-3.0$ & $3.0-3.4$ & $>3.4$ \\
\hline $\begin{array}{l}\text { Shoreline erosion/ } \\
\text { accretion }(\mathrm{m} / \mathrm{yr})\end{array}$ & $\begin{array}{l}>2.0 \\
\text { Accretion }\end{array}$ & $1.0-2.0$ & $\begin{array}{c}-1.0-+1.0 \\
\text { Stable }\end{array}$ & $-1.1--2.0$ & $\begin{array}{l}<-2.0 \\
\text { Erosion }\end{array}$ \\
\hline Mean tide range $(\mathrm{m})$ & $>6.0$ & $4.1-6.0$ & $2.0-4.0$ & $1.0-1.9$ & $<1.0$ \\
\hline $\begin{array}{l}\text { Mean wave height } \\
(\mathrm{m})\end{array}$ & $<0.55$ & $0.55-0.85$ & $0.85-1.05$ & $1.05-1.25$ & $>1.25$ \\
\hline
\end{tabular}

The index allows the six (6) physical variables to be related in a quantifiable manner. Once each section of coastline is assigned a risk value based on each specific data variable, the coastal vulnerability index is calculated as the square root of the geometric mean, or the square root of the product of the ranked variables divided by the total number of variables as:

$$
C V I=\sqrt{\left(\frac{a \times b \times c \times d \times e \times f}{6}\right)}
$$

where, $\mathrm{a}=$ geomorphology, $\mathrm{b}=$ coastal slope, $\mathrm{c}=$ relative sealevel rise rate, $\mathrm{d}=$ shoreline erosion/accretion rate, $\mathrm{e}=$ mean tide range, and $\mathrm{f}=$ mean wave height.

\section{ACCESSING COASTAL VULNERABILITY INDEX}

Around the world, the long-term goal of coastal vulnerability assessment is to predict coastal changes with a degree of certainty useful for coastal sustainable management (Thieler and
Hammar-Klose, 1999). This information is vital for decisionmaking regarding coastal development in both the short and long-term.

Pendleton et al. (2010) investigate CVI along the coast of Northern Gulf of Mexico, ranking the following primary six (6) physical variables from previously published data sources (from year 1985-2009), much like Thieler and Hammar-Klose (1999). Table 2 shows CVI variables which include both quantitative and qualitative information. There is a difference in quantitative variable of coastal slope between Hammar-Klose and Thieler (2001) and Pendleton et al. (2010), which based on actual value from their respective coastal slope information.

The calculated CVI values for the Northern Gulf of Mexico is based on NOS/NOAA water-level recorders for sea-level rise rate (Zervas, 2001), geomorphology, shoreline change from Dolan et al. (1988), wave height, coastal slope, and tidal. 
The International Archives of the Photogrammetry, Remote Sensing and Spatial Information Sciences, Volume XLII-4/W16, 2019 6th International Conference on Geomatics and Geospatial Technology (GGT 2019), 1-3 October 2019, Kuala Lumpur, Malaysia

Table 2. Ranges for vulnerability ranking of variables along the Northern Gulf of Mexico Coast (Pendleton et al., 2010)

\begin{tabular}{|c|c|c|c|c|c|}
\hline & \multicolumn{5}{|c|}{ Ranking of coastal vulnerability index } \\
\hline & Very low & Low & Moderate & High & Very High \\
\hline VARIABLE & 1 & 2 & 3 & 4 & 5 \\
\hline Geomorphology & $\begin{array}{l}\text { Rocky, cliffed } \\
\text { coasts, Fiords } \\
\text { Fiards }\end{array}$ & $\begin{array}{l}\text { Medium cliffs, } \\
\text { Indented coasts }\end{array}$ & $\begin{array}{l}\text { Low cliffs, } \\
\text { Glacial drift, } \\
\text { Alluvial plains }\end{array}$ & $\begin{array}{l}\text { Cobble } \\
\text { beaches, } \\
\text { Estuary, } \\
\text { Lagoon }\end{array}$ & $\begin{array}{l}\text { Barrier beaches, } \\
\text { Sand Beaches, } \\
\text { Salt marsh, } \\
\text { Mud flats, } \\
\text { Deltas, } \\
\text { Mangrove, } \\
\text { Coral reefs }\end{array}$ \\
\hline Coastal slope (\%) & $>1.20$ & $1.20-0.90$ & $0.90-0.60$ & $0.60-0.30$ & $<0.30$ \\
\hline $\begin{array}{l}\text { Relative sea-level } \\
\text { change }(\mathrm{mm} / \mathrm{yr})\end{array}$ & $<1.8$ & $1.8-2.5$ & $2.5-3.0$ & $3.0-3.4$ & $>3.4$ \\
\hline $\begin{array}{l}\text { Shoreline erosion/ } \\
\text { accretion }(\mathrm{m} / \mathrm{yr})\end{array}$ & $\begin{array}{l}>2.0 \\
\text { Accretion }\end{array}$ & $1.0-2.0$ & $\begin{array}{l}-1.0-+1.0 \\
\text { Stable }\end{array}$ & $-1.1--2.0$ & $\begin{array}{l}<-2.0 \\
\text { Erosion }\end{array}$ \\
\hline Mean tide range $(\mathrm{m})$ & $>6.0$ & $4.0-6.0$ & $2.0-3.99$ & $1.0-1.99$ & $<0.99$ \\
\hline $\begin{array}{l}\text { Mean wave height } \\
(\mathrm{m})\end{array}$ & $<0.55$ & $0.55-0.85$ & $0.85-1.05$ & $1.05-1.25$ & $>1.25$ \\
\hline
\end{tabular}

The mean CVI value is 20.96 ; the mode and median are both 22.82. The standard deviation is 6.63 . When compare to study by Hammar-Klose and Thieler (2001), the calculated CVI values range from 1.2 to 39.5 . The mean CVI value is 15.25 ; the mode is 7.3; and the median is 15.5. The standard deviation is 7.. Pendleton et al. (2010) shows an increase in CVI value range, mode and median and low standard deviation compared to Hammar-Klose and Thieler (2001).

Nevertheless, the mapped CVI values show large areas of very high vulnerability, particularly along the Louisiana - Texas coast for both studies (see Figure 2 and 3). The highestvulnerability areas are typically lower-lying beach and marsh areas; their susceptibility is primarily a function of geomorphology, coastal slope and rate of relative sea-level rise. On the Gulf of Mexico coast, much of the vulnerability is due to geomorphology and tide range; two variables which are ranked as generally high for the entire Gulf of Mexico region.

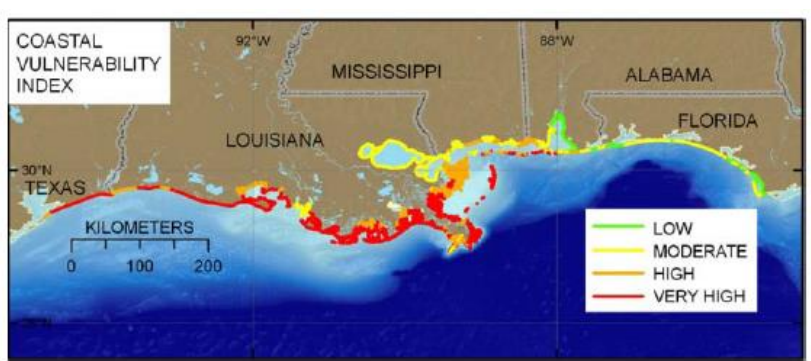

Figure 2. Northern Gulf of Mexico CVI calculated using Dolan et al. (1988) shoreline change data and sea-level rise rate from

NOS/NOAA water-level gages (Pendleton et al., 2010)

In the Northern Ireland, McLaughlin and Cooper (2010) investigate the implications of spatial scale in depicting coastal vulnerability assessment at three (3) different scales, national (Northern Island), local authority and site level. Three (3) different spatial resolution of the study area cause coastal variables to become obsolete as resolution increases to the local level. A greater level of detail is required at the local scale in order to distinguish between areas of potential vulnerability.

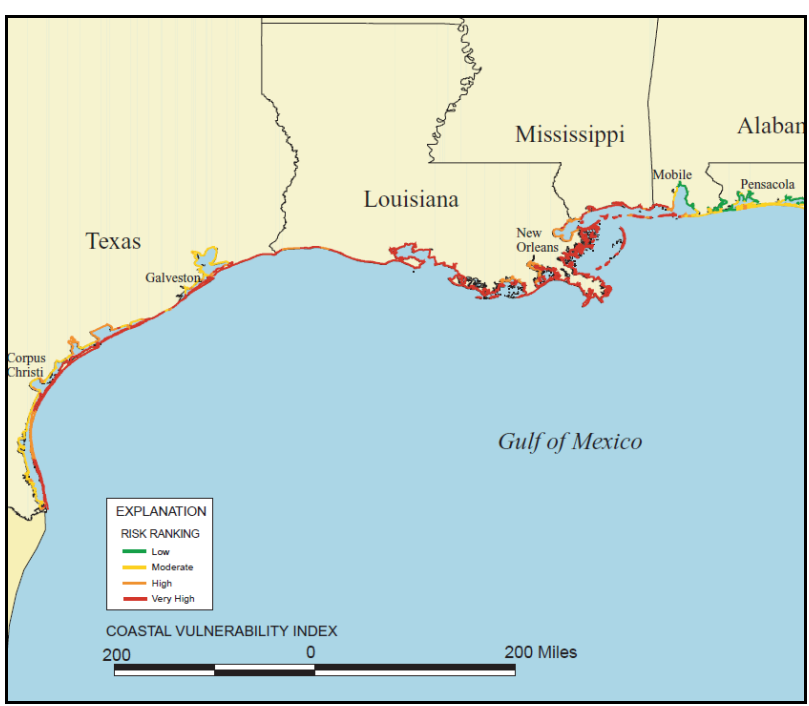

Figure 3. Map of the Coastal Vulnerability Index (CVI) for the

U.S. Gulf coast (Thieler and Hammar-Klose, 2001)

Ultimately, at Northern Ireland Index level, the East Strand at Portrush is classified as being predominantly in the 40-60 vulnerability category, decreasing to $20-40$ at regional level, at local scale, the beach is predominantly in the vulnerability range $0-20$.

These results show that the scale of study determine different outcome at different scale; in which the area can be regarded vulnerable at one scale, but not at another. While the results between different scales cannot be directly compared, McLaughlin and Cooper (2010) normalised the index values at each scale so that each value is relative to the full range of values calculated at that scale. Eventually, this study features a nested approach to index development and reinforcing the importance of scale in determining policy response to vulnerability. 


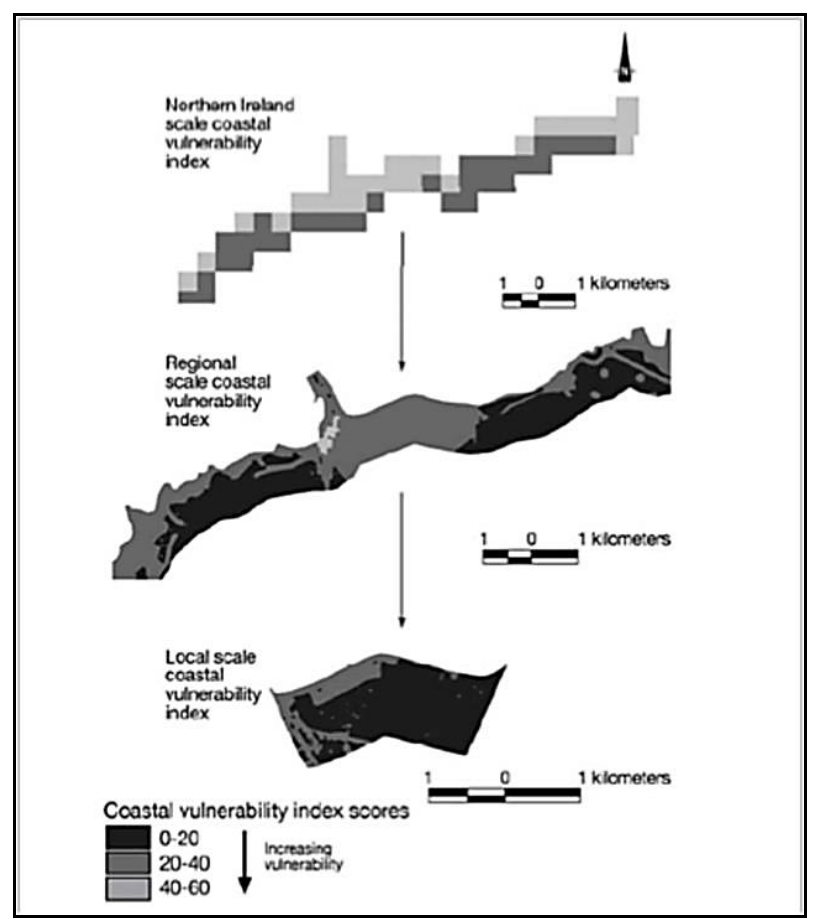

Figure 4. Map showing three spatial scales used in the study: Northern Ireland, Coleraine Borough Council and Portrush East Strand (McLaughlin and Cooper, 2010)
Previously, as stated in Section 2.2, socio-economic variables tend to cultural bias to the vulnerability index since socioeconomic variables are difficult to quantify (Gornitz et al., 1993; McLaughlin and Cooper, 2010). Kantamaneni et al. (2018) however access coastal vulnerability by combining physical and economic index. They favourably develop new Physical Coastal Vulnerability Index (PCVI) and apply it across England and Wales. PCVI outputs then compare and contrast with new Fiscal Coastal Vulnerability (FCVI), which enable coastal areas to be visually classify in one of four categories to inform relative risk. Both indices are subsequently integrated into a Combined Coastal Vulnerability Index (CCVI).

Table 3 details seven (7) PCVI variables use to access physical coastal vulnerability which based on Palmer et al. (2011). Economic variables as shown in Table 4 are originally obtained using Balica et al. (2012) indicator-based methodology where following assessment and trend analyses 20 initial parameters are reduced to the six consider most significant. Data is collected from various organisations regarding number of properties, economic value of location, current market prices, population and flooding frequency. These values are then used to determine economic thresholds and classifications 'extremely low', 'low', 'moderate', 'high' and 'extremely high', enabled a semi-quantitative assessment of fiscal vulnerability.

Table 3. Physical parameter ratings associated with different levels of vulnerability (Palmer et al., 2011; Kantamaneni et al., 2018)

\begin{tabular}{l|c|c|c|c}
\hline \multicolumn{1}{c|}{ Physical variables } & Very low & Low & Moderate & High \\
\hline Beach width & $\mathbf{1}$ & $\mathbf{2}$ & $\mathbf{3}$ & $\mathbf{4}$ \\
\hline Dune width & $>150 \mathrm{~m}$ & $100-150 \mathrm{~m}$ & $50-100 \mathrm{~m}$ & $<50 \mathrm{~m}$ \\
\hline Coastal slope & $>150 \mathrm{~m}$ & $50-150 \mathrm{~m}$ & $25-50 \mathrm{~m}$ & $<25 \mathrm{~m}$ \\
\hline Distance of vegetation behind the back beach & $12 \%$ & $12-8 \%$ & $8-4 \%$ & $<4 \%$ \\
\hline Distance of built structures behind the back beach & $>600 \mathrm{~m}$ & $200-600 \mathrm{~m}$ & $100-200 \mathrm{~m}$ & $<100 \mathrm{~m}$ \\
\hline Rocky outcrop & $>600 \mathrm{~m}$ & $200-600 \mathrm{~m}$ & $100-200 \mathrm{~m}$ & $<100 \mathrm{~m}$ \\
\hline Sea defences & $>50 \%$ & $20-50 \%$ & $10-20 \%$ & $<10 \%$ \\
\hline
\end{tabular}

Table 4. Coastal economic vulnerability parameters and threshold values (m, millions) (Balica et al., 2012; Kantamaneni et al., 2018)

\begin{tabular}{l|c|c|c|c|c}
\hline & Very low & Low & Moderate & High & Very High \\
\hline \multicolumn{1}{c|}{ Fiscal parameters } & $\mathbf{1}$ & $\mathbf{2}$ & $\mathbf{3}$ & $\mathbf{4}$ & $\mathbf{5}$ \\
\hline Commercial properties & $<2 \mathrm{~m}$ & $2-10 \mathrm{~m}$ & $10-30 \mathrm{~m}$ & $30-70 \mathrm{~m}$ & $>70 \mathrm{~m}$ \\
\hline Residential properties & $<30 \mathrm{~m}$ & $30-80 \mathrm{~m}$ & $80-130 \mathrm{~m}$ & $130-180 \mathrm{~m}$ & $>180 \mathrm{~m}$ \\
\hline Economic value of site & $<10 \mathrm{~m}$ & $10-50 \mathrm{~m}$ & $50-100 \mathrm{~m}$ & $100-150 \mathrm{~m}$ & $150 \mathrm{~m}$ \\
\hline Population & $<500$ & $500-2000$ & $>2000-5000$ & $5000-10,000$ & $>10,000$ \\
\hline Coastal erosion & $<0.3 \mathrm{~m}$ & $0.3-9 \mathrm{~m}$ & $2.6-5 \mathrm{~m}$ & $5-9 \mathrm{~m}$ & $>9 \mathrm{~m}$ \\
\hline Flood (event) impact & $<3 \mathrm{~m}$ & $3-9 \mathrm{~m}$ & $>9-15 \mathrm{~m}$ & $15-35 \mathrm{~m}$ & $>35 \mathrm{~m}$ \\
\hline
\end{tabular}

Great Yarmouth's PCVI) is higher than its FCVI as shown in Figure 5, but Aberystwyth's FCVI is higher than all eleven investigation sites. Great Yarmouth has the highest vulnerability according to CCVI value, because of its high population and rapid coastal infrastructure expansion.

Spurn Head has a high physical ranking but a low economic ranking, which is influenced by its sand and shingle spit morphology that is not conducive to construction and population growth. The Port Talbot and Llanelli regions are centred on industry, they contain large numbers of residential and commercial properties. However, these areas are generally protected by sea defences.

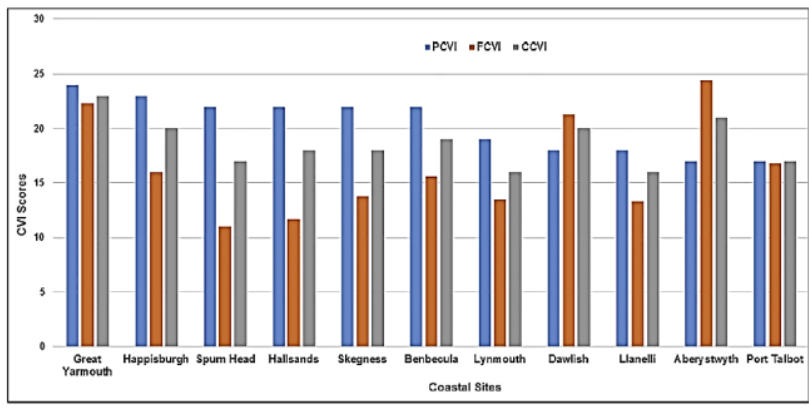

Figure 5. Representation of coastal vulnerability indices (Kantamaneni et al., 2018) 
Combining PCVI with FCVI transform our frequent way in assessing coastal vulnerability and eventually inform future planning and redevelopment decisions. Socio-economic and ecological components are very significant and requires consideration when assessing coastal zone vulnerability and management options. These aspects are subjects of on-going research, but this method of estimating vulnerability will ultimately allow cost-benefit analysis.

Archipelago countries like Indonesia have developed coastal vulnerability assessment by utilizing technological advances, from satellite imageries to Geographic information system (GIS). This technique actually revolutionized current CVI development as assessing conventional physical attributes from conventional methods is tedious and costly to implement. Loinenak et al. (2015) map CVI of Doreri Bay, West Papua Province with the aid of GIS and satellite imageries.

Source of their data mainly from satellites, with data on geomorphology variables are obtained from the satellite image Aster DEM 30m and RBI map sheet, coastline changes from the satellite image of Landsat TM 1989 and ETM+ 2013, the coastline slope from the satellite image of Aster DEM 30m, sea level trend from the satellite image of Altimeter TOPEX/POSEIDON. JASON 1 and JASON 2, the European Centre for Medium-Range Weather Forecasts (ECMRWF) provides mean wave height, and the average tidal heights from the literature review and the Hydro- Oceanography Service of the National Army Navy. Data for each variable are classified using a vulnerability matrix which was developed based on the literature review and spatial analysis through scoring and weighting.

Meanwhile Semedi et al. (2016) determine the physical coastal vulnerability index using satellite imagery and GIS in coastal areas of Denpasar, Bali, Indonesia. The data sources are from satellite imagery of Landsat 8, Aster GDEM satellite imagery, TOPEX-Poseidon-Jason 1-Jason 2 satellite imagery whereas sea level and wave height variables source of data is from conventional method. They also weight each parameter to determine how much impact is generated by oceanographic factors such as wave.

Interestingly, Husnayaen et al. (2018) has accessed CVI by adding physical variable of land subsidence, which information are obtained from Synthetic Aperture Radar (SAR) of remote sensing data, the Advanced Land Observing Satellite (ALOS) Phased Array type L-band SAR (PALSAR). Husnayaen et al. firstly addresses identification of the primary variables influencing the coastal vulnerability and coastal evolution in general, a step that should be considered in deciding suitable physical components that influencing vulnerability of the coast. Besides, they also address land subsidence as one of the physical variables due to satellite altimeter only provides absolute sea level information.

Range of vulnerability information of this study follows Pendleton et al. (2010) (see Table 2) and compare CVI value of six (excluding land subsidence) coastal parameters with CVI of seven parameters. The coastal vulnerability as estimated by CVI significantly increases when the land subsidence parameter is included as illustrated in Figure 6.

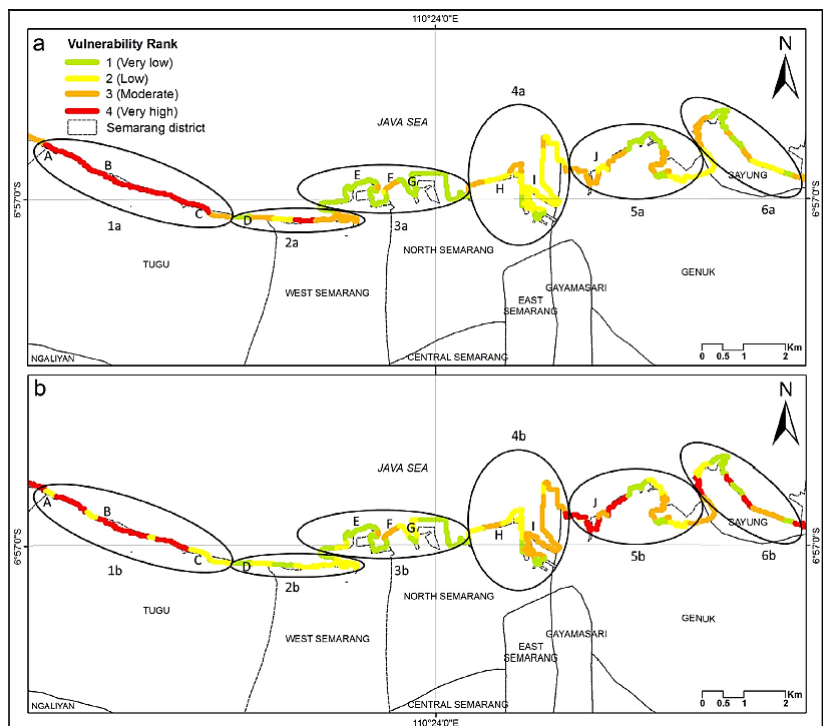

Figure 6. Comparison of the CVI in Semarang, Indonesia (a) 6parameters CVI (b) 7-parameters CVI (Husnayaen et al., 2018)

Field survey is conducted for ground check and validation by applying Kappa coefficient $\left(\mathrm{K}_{\mathrm{hat}}\right)$, which is often used in remote sensing validation to measure the agreement between interpretation and real condition in the field. They find out that the CVI 7 parameters are more suitable for coastal vulnerability in Semarang based on the agreement calculated between the CVI and field survey.

In Malaysia, CVI assessment is commonly regarded to assess coastal vulnerability along the coast of Malaysia. Mohamad et al (2014) develop a CVI along the coast of Peninsular Malaysia. Table 5 displays physical variables that have been used by Mohamad et al to assess CVI along the coast of Peninsular Malaysia. Based on Table 5, they replace commonly use physical variable of coastal slope to maximum current speed. A total of $1963 \mathrm{~km}$ of coastline was evaluated and of this and the outcome indicates that $3.3 \%$ of the mapped shoreline is classified as category 5, these sites are southern stretches of Terengganu shoreline and northern reaches of Kedah shoreline as shown in Figure 7. Results have shown that $11 \%$ of Peninsular Malaysia shoreline is classified as category 4 and 40 $\%$ as category 3 .

Identification of physical variables that suitable for a certain coastal area based on its special coastal characteristic may have impacts on the coastal vulnerability assessment. Mohd et al. (2018) study aim to identify physical variables that suitable for Pahang's coast in order to develop CVI. Seven (7) physical variables have been identified to assess the CVI that consists of geomorphology, coastal slope, shoreline change rate, mean significant wave height, mean tidal range, relative sea level rate and land use. A comprehensive CVI was obtained by integrating the differential weighted rank values of the variables. 
The International Archives of the Photogrammetry, Remote Sensing and Spatial Information Sciences, Volume XLII-4/W16, 2019 6th International Conference on Geomatics and Geospatial Technology (GGT 2019), 1-3 October 2019, Kuala Lumpur, Malaysia

Table 5. Ranges for vulnerability ranking of variables along the Northern Gulf of Mexico Coast (Mohamad et al., 2014)

\begin{tabular}{l|c|c|c|c|c}
\hline \multirow{2}{*}{\multicolumn{1}{c|}{ VARIABLE }} & \multicolumn{5}{c}{ Ranking of coastal vulnerability index } \\
\cline { 2 - 6 } & Very low & Low & Moderate & High & Very High \\
\hline Geomorphology & $\mathbf{1}$ & $\mathbf{2}$ & $\mathbf{3}$ & $\mathbf{4}$ & $\mathbf{5}$ \\
\hline Maximum current speed (m/s) & $\begin{array}{c}\text { Rocky, } \\
\text { coasts }\end{array}$ & $\begin{array}{c}\text { Composite } \\
\text { of sand and } \\
\text { rocks }\end{array}$ & $\begin{array}{c}\text { Sand } \\
\text { Remposite of } \\
\text { clay and rock } \\
\text { or sand }\end{array}$ & $\begin{array}{c}\text { Mud } \\
\text { flats }\end{array}$ \\
\hline Relative sea-level change (mm/yr) & $0-0.2$ & $0.2>0.4$ & $0.4-0.6$ & $0.6-0.8$ & $0.8-1$ \\
\hline Shoreline erosion rate (m/yr) & $<1.8$ & $1.8-2.5$ & $2.5-3.0$ & $3.0-3.4$ & $>3.4$ \\
\hline Mean tide range (m) & $>+8$ & +3 to +7 & -1 to +3 & -5 to -1 & $<-5$ \\
\hline Significant wave height $(\mathrm{m})$ & $>3.5$ & $3-3.5$ & $2.5-3$ & $2-2.5$ & 0 \\
\hline
\end{tabular}

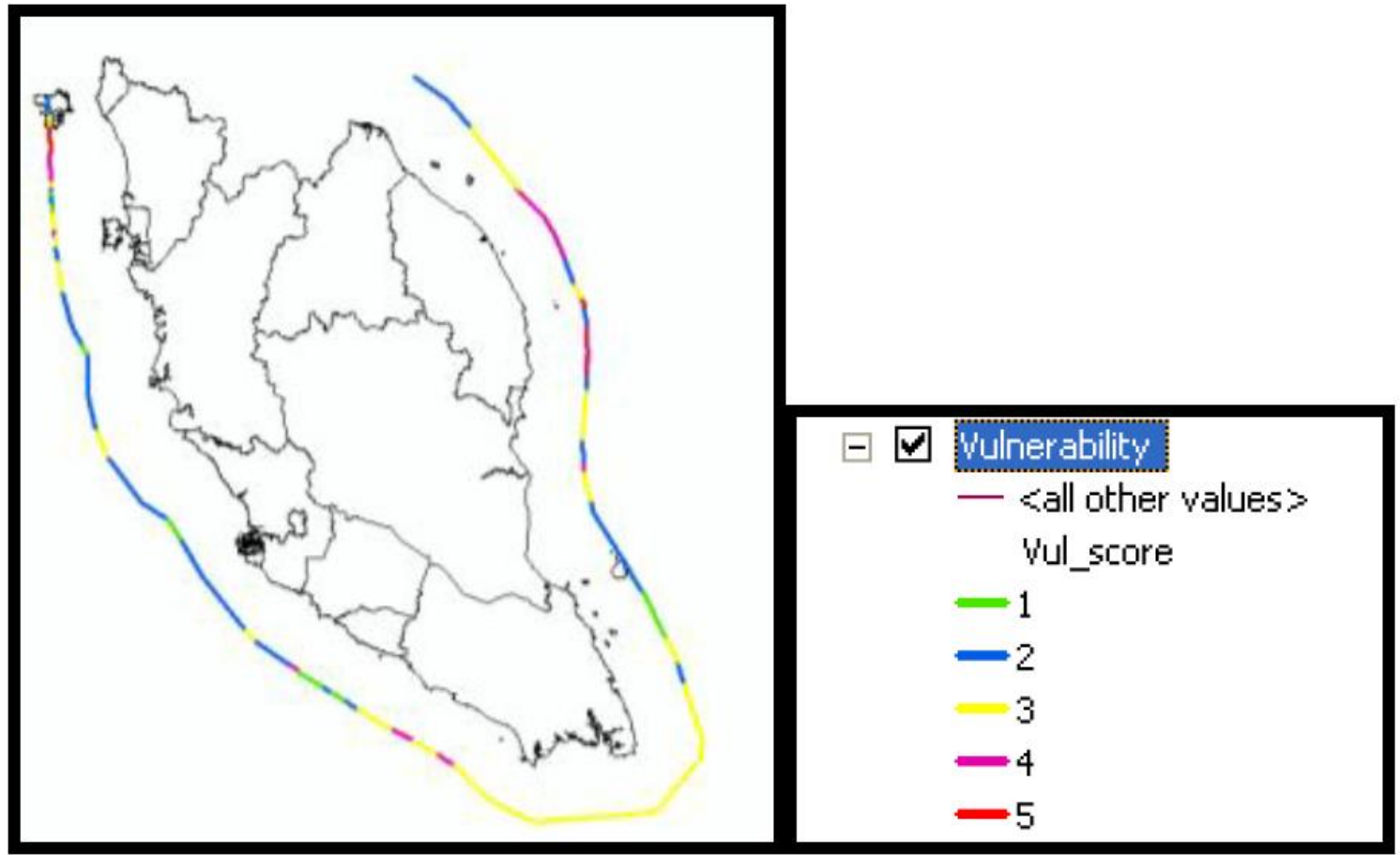

Figure 7. Peninsular Malaysia CVI based on study by Mohamad et al. (2014)

Based on classification method, the land use and land cover pattern of shoreline along the Pahang coastal have changed within 8 years period of 2006 until 2014. Based on in-situ observation, the main land use and land cover that exists along Kuantan to Pekan shoreline is an agricultural sector. The second dominant land use pattern is urban and commercial areas especially in the Kuantan city. District of Kuantan to Pekan is a quite less developed area except for Kuantan town at the north (Mohd et al., 2018).

\section{CONCLUSION}

Coastal vulnerability assessment is vital for the insight into the relative potential of coastal changes everywhere. CVI can provide awareness towards the relative potential of coastal damage cause by sea-level rise. They, of necessity, rely on what data are available rather than what might be desired in an ideal world. Coastal index development has the capacity to be used in assisting with devising coastal policy. Additional potential physical variables should be taken into consideration in vulnerability assessment particularly in Malaysia, as Malaysia coastal area has a diverse geomorphological condition as well.

\section{ACKNOWLEDGEMENTS}

The authors would like to express appreciation to Universiti Teknologi Malaysia (UTM) and the Ministry of Energy, Science, Technology, Environment and Climate Change (MESTECC) for funding this research under the International Collaboration Fund (ICF), Vote Number R.J130000.7901.4S142.

\section{REFERENCES}

Balica, S., Wright, N.G., van der Meulen, F., 2012. A flood vulnerability index for coastal cities and its use in assessing climate change impacts. Nat. Hazards 64, 73-105.

Cooper, J. A. G. and McLaughlin, S., 1998. Contemporary multidisciplinary approaches to coastal classification and environmental risk analysis. Journal of Coastal Research, 14(2). Page no. 512-524.

Dal Cin, R. and Simeoni, U., 1989. Coastal zoning and vulnerability: application to the Middle Adriatic (Italy). Coastal Zone '89. Page no. 98-110. 
Dolan, Robert., Anders, F.J, and Kimball, Suzette, 1988, Coastal erosion and accretion: National Atlas of the United States of America: U.S. Geological Survey, Reston, Virginia, 1 sheet, scale 1:7,500,000.

Din, A. H. M., Zulkifli, N. A., Hamden, M. H., \& Aris, W. A. W. 2019. Sea level trend over Malaysian seas from multimission satellite altimetry and vertical land motion corrected tidal data. Advances in Space Research, 63(11), 3452-3472. https://doi.org/10.1016/j.asr.2019.02.022

Gornitz, V., Daniels, R. C., White, T. W. and Birdwell, K. R., 1993. The development of a coastal risk assessment database: Vulnerability to sea-level rise in the U.S. Southeasts. DEAC05-84OR21400, US Government Report, Oak Ridge National Laboratory, TN

Hammar-Klose, E. S. and Thieler, E. R., 2001. Coastal vulnerability to sea-level rise: a preliminary database for the US Atlantic, Pacific and Gulf of Mexico coasts. US Geological Survey, Coastal and Marine Geology Program. https://pubs.usgs.gov/dds/dds68/htmldocs/project.htm Accessed 30 Mac 2019.

Hamid, A. I. A., Din, A. H. M., Hwang, C., Khalid, N. F., Tugi, A., \& Mohd, K. 2018. Journal of Asian Earth Sciences Contemporary sea level rise rates around Malaysia : Altimeter data optimization for assessing coastal impact. Journal of Asian Earth Sciences, 166(October 2017), 247-259. http://doi.org/10.1016/j.jseaes.2018.07.034

Husnayaen, Rimba, A. B., Osawa, T., Parwata, I. N. S., Assyakur, A. R., Kasim, F., \& Astarini, I. A., 2018. Physical assessment of coastal vulnerability under enhanced land subsidence in Semarang, Indonesia, using multi-sensor satellite data. Advances in Space Research, 61(8). Page no. 2159-2179.

Kantamaneni, K., Phillips, M., Thomas, T., \& Jenkins, R. 2018. Assessing coastal vulnerability: Development of a combined physical and economic index. Ocean and Coastal Management, 158 (April 2017), 164-175. http://doi.org/10.1016/j.ocecoaman.2018.03.039

LOICZ (Land-Ocean Interactions in the Coastal Zone), 1995. LOICZ typology: Preliminary version for discussion. LOICZ Reports and Studies No. 3. Texel, The Netherlands.

Loinenak, F., Hartoko, A., \& Muskananfola, M., 2015. Mapping of Coastal Vulnerability using the Coastal Vulnerability Index and Geographic Information System. International Journal Of Technology, 6(5), 819-827. doi:10.14716/ijtech.v6i5.1361

McFadden, L. 2007. Vulnerability Analysis: A Useful Concept for Coastal Management. Managing Coastal Vulnerability: An Integrated Approach. Elsevier Ltd,. Page no. 16-28.

McLaughlin, S. and Cooper, J. A. G., 2010. A multi-scale coastal vulnerability index: A tool for coastal managers?. Environmental Hazards 9 (2010) Page no. 233-248.

MEA - Millennium Ecosystem Assessment, 2005. Ecosystems and human well-being: current state and trends. Chapter 19 Coastal systems. Island Press, Washington DC, USA. 815 pages.
Mohamad, M. F., Lee, L. H., Kamarul, M., \& Samion, H., 2014. Coastal Vulnerability Assessment towards Sustainable Management of Peninsular Malaysia Coastline, 5(6). http://doi.org/10.7763/IJESD.2014.V5.540

Mohd, F. A., Nizam, K., Maulud, A., Karim, O. A., Begum, R. A., \& Khan, F., 2018. An Assessment of Coastal Vulnerability of Pahang 's Coast Due to Sea Level Rise, 7, 176-180.

Palmer, B.J., Van der Elst, R., Mackay, F., Mather, A.A., Smith, A.M., Bundy, S.C., Thackeray, Z., Leuci, R., Parak, O., 2011. Preliminary coastal vulnerability assessment for KwaZulu-Natal, South Africa. J. Coast. Res. 64, 1390-1395.

Pendleton, B. E. A., Barras, J. A., Williams, S. J., Twichell, D. C., \& Survey, U. S. G. (2010). Coastal Vulnerability Assessment of the Northern Gulf of Mexico to Sea-Level Rise and Coastal Change.

Quelennec, R. E., 1989. The Corine 'Coastal Erosion Project': identification of coastal erosion problems and data base on the littoral environment of eleven European countries. Coastal Zone '89, 4594-4601

Ramieri, E., Hartley, A., Barbanti, A., Santos, F. D., Gomes, A., Laihonen, P., Santini, M. (2011). Methods for assessing coastal vulnerability to climate change, 1-93.

Semedi, B., Husain, B. H., \& Hidayati, N., 2016. Analyzing Coastal Vulnerability Index Using Integrated Satellite Remote Sensing and Geographic Information System : A Case Study of Denpasar Coastal Zone, 6(4), 35-40.

Thieler, E.R., and Hammar-Klose, E.S., 1999, National assessment of coastal vulnerability to future sea-level ise: Preliminary results for the U.S. Atlantic Coast: U.S. Geological Survey, Open-File Report 99-593, 1 sheet, accessed at: http://pubs.usgs.gov/of/1999/of99-593/.

Williams, A.T., et al., 1993. A checklist assessment of dune vulnerability and protection in Devon and Cornwall, UK. Coastal Zone'93, pp. 3394-3408

Zervas, C., 2001, Sea level variations of the United States 18541999: NOAA Technical Report NOS CO-OPS 36, 201 p.

\section{Revised August 2019}

